\title{
Factors Leading To Success Of Tourism Business In Bangkok Thailand
}

Chayanan Kerdpitak, Valaya Alongkorn Rajabhat University, Thailand

\begin{abstract}
The research on Factors Leading to the Success of a Tourism Business aims to 1) study the current condition of the tourism business 2) study the guideline for tourism business development 3) study marketing innovation and tour program arrangement and the competition strategies of the tourism business 4) study the business success of the tourism business management 5) study the influencing factors to business success of tourism business. Quantitative and qualitative researches have been applied as research methodology. The population includes tourism companies in Bangkok. The unit of analysis is a tourism organization. The simple random sampling is used to select the sample for the quantitative research. The sample used for data collection includes 339 tourism business operators and managers, and the instrument used is a questionnaire. The purposive sampling method selection is used to collect the sample for the qualitative research. The data have been collected from the tourism business operators or managers by means of in-depth interview. The data have been analyzed by using the descriptive statistics, and the path analysis has been applied for equation analysis.

According to the study result, the factors of the marketing innovation, the tour program arrangement and the competition strategies influence the business success of the tourism business management by having the influential level of 42.6 percent. There are 45 main factors that can be used for the success of the business. The current condition of the tourism business is highly competitive. Marketing innovations are always applied for the competition. In addition, the tour program arrangement is significant, and it must be adjusted for the high season. The guideline used for the tourism business development includes the differentiation of the tour program arrangement, the price and the service quality, such as accommodations, vehicles, food, safety and clients' needs.
\end{abstract}

Keywords: Business Success; Tourism Business; Tour Program Arrangement; Marketing Innovation

\section{INTRODUCTION}

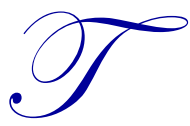

ourism is the industry that generates the main income for Thailand. Thus, the government continues supporting and promoting the tourism industry, leading to the incessant growth of the tourism industry. (Department of tourism: Ministry of tourism and sports, 2016) Moreover, the tourism business has also expanded to foreign markets. The tourism is the business that leads to the direct and indirect country development (PATA, 2012). Therefore, the various aspects of the tourism should be supported and promoted to ensure the same quality to that of foreign countries and international acceptance. The tourism is the main activity that creates happiness among consumers. (Department of tourism: Ministry of tourism and sports, 2016; World Travel and Tourism Council, 2015) By this reason, business operators who can satisfy the consumers can rapidly expand their businesses (Dimanche \& Havitz, 1994; Crotts \& Bing, 2007). At present, the tourism is the business that generates high income, also leading to high competition. Thus, it is always necessary for the business operators to focus on the development of the various aspects of their businesses, being based on developing and responding to clients' needs and satisfaction. Meanwhile, the business operators must take their costs and profits into account. Those who can operate their businesses with low costs can make higher profits, sustaining their businesses amid severe competition (Chen, 1998; Hwang, Lee, \& Chen, 2005; Barney, 1991). Those who can differentiate their products and services will bring more customers to buy their products and services, leading to rapid business growths and high profits. Furthermore, the business must be managed by also focusing on marketing. The business becomes more competitive now. The traditional marketing cannot draw clients' attention to products and services, so business operators must apply marketing techniques that help attract more clients and more quickly (Oliver \& Swan, 1989; Vargas, Cardenas, \& Matarranz, 2000; Kozak, \& Rimmington, 2000; Kozak, 2002; Kerdpitak \& Heuer, 2013; Kerdpitak \& Heuer, 2016; Kotler, 1997). 
This study thus aims to study the essential contents that lead to the success of the tourism business by studying the factors that can lead to business development and differentiate products and services and the use of lower costs than those of competitors.

\section{REVIEW OF THE LITERATURE}

\section{Marketing Innovation: MAIN}

The marketing innovation is a strategy that makes the tourism business successful and enables the business to reach the target groups of clients rapidly and continuously, enabling the clients to choose products and services they want. Meanwhile, the clients can compare the products and the services to those of other business operators before they make their decisions to buy the products and the services. The business operators who still use traditional marketing techniques for their businesses will not be able to reach the target groups of clients although their products and services are developed, blocking the growths of their businesses and making the businesses fail to compete with those of the competitors. Thus, it is necessary for the business operators to focus on adopting innovative marketing techniques, including the creation of websites to present their products and services, the continued development of the websites, sales promotion via electronic mail, sending brochures via electronic mail, the creation of the payment system for products and services, encouraging clients to make their decisions more quickly. Additionally, the online system must be used to enable clients to see the products and the services, leading to quicker and easier decision-making (Barney, 2001; He \& Li, 2011; Park, Lee, Choi, \& Yoon, Y, 2012; Pennington-Gray, Schroeder, \& Gale, 2014; Kotler, 1997; Samuel \& Certo, 2012).

H1: Marketing innovation has a positive effect on tourism business

\section{Tour Program Arrangement: TOPA}

The tourist activity is the main factor of the tourism business that cannot be absent. According to the competition theory, the successful business must comprise the products and the services that correctly respond to the clients' needs and match the clients' satisfaction, leading the clients to decide and buy the products in the first place. In addition, the resource theory also states that the business that is competitive must possess valuable, rare, irreplaceable and inimitable resources. When this theory has been applied to the tourism business, the main activities of the tourism business must consist of quality tourist attractions, good food and standard accommodations. The quality tourist attractions must be the natural beauty of the tourist places, and the tourist attractions are rarely found in other places. There are uniquely local foods that are impossible to be replaced, or if they can be replaced, they are very expensive. Moreover, experienced tour guides are also a vital resource. By these reasons, it is possible to say that the main factors of the tourist activity comprises travel scheduling, tourist attractions, food, facilities, accommodations and safety. (Connell, 2012; Barrister, Lyiola, \& Osibanjo, 2014; Martínez, Pérez, \& del Bosque, I., 2014; Pennington-Gray, Schroeder, \& Gale, 2014).

H3: Tour program arrangement has a positive effect on tourism business

\section{Competitive Strategy: COST}

The competition is the strategy that ensures the success of the business. According to the competition theory, the business is superior to that of the competitors must be operated with low costs. In addition, the products and the services must be different from those of the competitors (Porter, 1985). Furthermore, to operate the business with low costs, it is necessary to recruit suppliers who can provide cheap raw materials or operating materials. Meanwhile, the sources of raw materials with cheaper prices than those of the competitors must be also recruited. Unnecessary time consumption must be reduced, and resources must be less consumed (Porter, 1985; Porter, 1990; Balmer \& Greyser, 2006). The theory also states that the more the products are different from those of competitors, more quickly clients will make their decisions. The differences of the goods and the services differing in terms of either the products or the prices can allow the clients to make their decisions more quickly. However, the differences of both factors can allow the clients to make their decisions even more quickly, increasing the competitiveness of the business (Porter, 1985; Porter, 1990; Kerdpitak \& Heuer, 2016; Kotler, 1997). 
H2: competitive strategy has a positive effect on tourism business

\section{Business Success: BUSU}

According to the competition theory, for the success of the business, business operators must increase their market shares, profits and sales for three years and over in a row. Besides, clients must be satisfied with products and services, being based on indicators and without complaints. The clients must use the services again and advise other clients to use the services. Also, businesses must take their operating costs into account (Martínez \& del Bosque, I., 2013; Kotler, 1997; Pennington-Gray, Schroeder, \& Gale, 2014; Certo \& Certo, 2012).

Figure 1. Conceptual Framework for Research

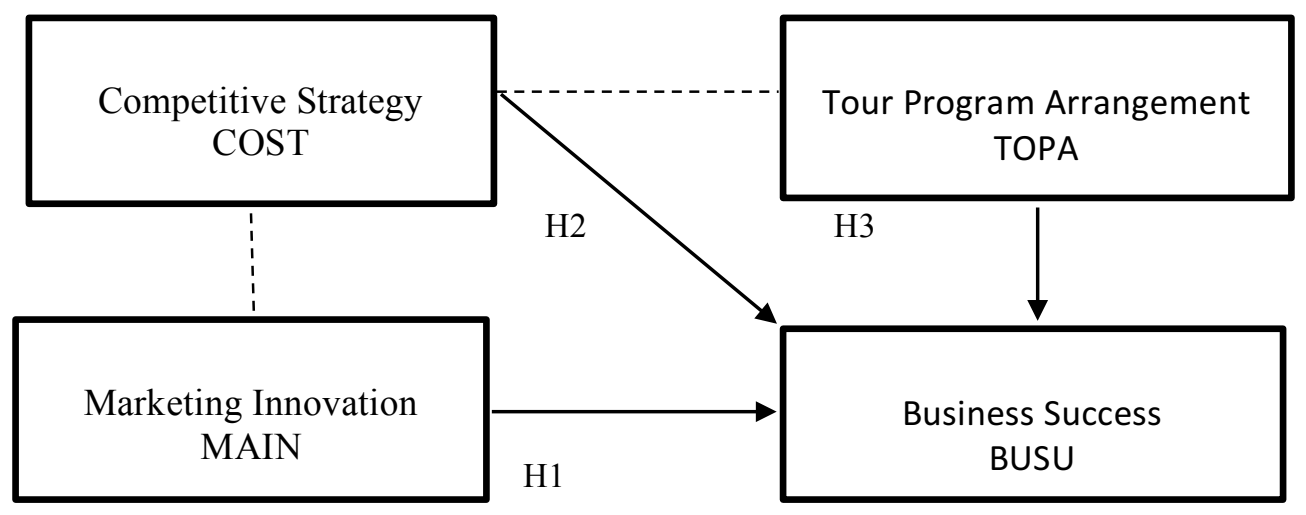

Equation for Research

$$
B U S U=\beta_{0}+\beta_{1} M A I N+\beta_{2} C O S T+\beta_{3} T O O P \zeta_{1}
$$

\section{METHODOLOGY}

The researcher used both qualitative and quantitative methods in carrying out this research investigation. Therefore, the research instruments were twofold. The qualitative research instrument involved conducting in-depth interviews in order to obtain relevant facts and elicit information showing what were the precise relationships among variables. Upon collecting this information, the researcher was thereupon able to construct a questionnaire to be used in the quantitative research phase of the investigation.

The quantitative research investigation required using a questionnaire constructed on the basis of a review of relevant literature and conducting in-depth interviews. As such, the research instruments were used to investigate 1) Marketing Innovation 2) Tour program arrangement 3) Competitive Strategy 4) Business Success The data were obtained from 339 tourism business sampling. The data collected were subsequently analyzed using the path modeling technique, utilizing SPSS as a tool for data analysis. (Pimpunchat, Sirimangkhala, \& Junyapoon, 2014; Taro, 1973).

\section{FINDINGS}

The result of the in-depth interview and the study of the general condition in the research area can be used for analysis and discussion as follows:

1. The innovative marketing has shown that the clients are interested in choosing and buying the products and the services that reach them by different methods, including websites for product presentation, sending the details of the products and the services via electronic mail, sending the details of the products and the services by mobile phone, Facebook, Line, Twitter and VDO Call. Apart from reaching the 
clients, these methods can improve the clients' perception and motivate decision-making. In addition, it is possible to use other marketing activities, such as various aspects of sales promotions.

2. The tour program arrangement has shown that the essential content of the activitymust be emphasized, as the tourism activity acts as a main product and service. If the main product and service is not good, the clients will not buy the products or use the services. The qualities of the activity comprise splendid, clean, convenient and popular tourist attractions, quality tourist guides with sufficient experiences and good tour programs. These qualities can save the clients' time. The tour programs must be on time, and the food and drinks are seasonal. Meanwhile, the local food is popular.

3. The competition strategy has shown that the business costs are low, and theproducts and the services are different from those of the competitors. These factors include the recruitment of business partners for cost reduction during the low season, finding the sources of raw materials, office equipment or raw materials used for low price products and services. The tour programs are quality, as tourists spend less time to see the natural beauty and visit various tourist attractions. By these reasons, the operating cost is low. The tour programs are different in terms of beauty and prices, allowing the tourists to make their decisions more quickly.

4. The success of the business has had three factors, including marketing innovation,tourist activity arrangement and competition strategy, the details of which are as follows: The marketing innovation is used for promoting the marketing activity of the business, allowing the business to reach its target market. Besides, it is convenient for the clients to receive information and news. Meanwhile, the business can improve recognition, encouraging rapid purchases in the market. The tourist activity must consist of quality and popular tourist attractions and freshly local food in the region, and the food must be tasty. The tour guides must possess experiences in terms of the services and the language skills. For the competition strategy of the business, the business must use the low operating cost by building the business alliance for sharing resources. The costs of accommodations, transportations and other expenses must be lower. Meanwhile, the tour programs and the prices must be different, allowing the clients to choose and buy the products and the services.

5. For the tourism business development guideline, business operators must seriouslyfocus on their qualities in various aspects, comprising finding quality tourist attractions. The tourist attractions must be able to draw the tourists' attention. The tourist attractions are safe without theft or communicable diseases. The food must be adjusted to match with the tourists' taste. The tour routes must be improved, and there must be a variety of travel methods. The tour guides must possess good quality in terms of the service, the knowledge and the language.

6. For the current condition of the tourism business, some tourism businesses aresuccessful, and the other tourism businesses fail, as they do not have sufficient experiences, and they have just entered the market, so the tourists are not satisfied with their services. Meanwhile, their tour programs do not match with what they have previously planned, and their food, accommodations and tour guides are low quality, so the tourists complain a lot and do not want to use the services again. Experienced tour companies can solve the problems, satisfying the clients and reducing the number of complaints. 
Table 1. Factors derived from in-depth interviews to be used to formulate a guideline for the solution of problems

\begin{tabular}{|c|c|c|c|c|}
\hline Variable & n & Mean & S.D. & Result \\
\hline \multicolumn{5}{|l|}{ Marketing Innovation } \\
\hline There is a website used for the promotion of a tour program & 339 & 3.54 & 0.47 & most \\
\hline $\begin{array}{l}\text { There is a website promoted by using a modern method, such as SEO to } \\
\text { attract more clients }\end{array}$ & 339 & 3.82 & 0.53 & most \\
\hline $\begin{array}{l}\text { There is email marketing used by reaching clients directly and reaching a } \\
\text { target market }\end{array}$ & 339 & 3.22 & 0.66 & middle \\
\hline There is a website developed to make it beautiful and outstanding all the time & 339 & 4.23 & 0.49 & mostly \\
\hline $\begin{array}{l}\text { Can a client see a website via other methods, such as a mobile phone and a } \\
\text { tablet }\end{array}$ & 339 & 4.56 & 0.51 & mostly \\
\hline There is a brochure sent to a target market via email & 339 & 4.44 & 0.67 & mostly \\
\hline $\begin{array}{l}\text { There is a website linked with the other website of a related business, } \\
\text { including a meeting business, MICE }\end{array}$ & 339 & 3.51 & 0.69 & most \\
\hline $\begin{array}{l}\text { There is an experienced agent hired to handle email marketing and reach the } \\
\text { target groups of clients }\end{array}$ & 339 & 3.68 & 0.71 & most \\
\hline $\begin{array}{l}\text { There is a tour program promoted in other online media, such as Facebook, } \\
\text { Twitter and Line }\end{array}$ & 339 & 4.43 & 0.74 & mostly \\
\hline $\begin{array}{l}\text { There is a tour program introduced with other businesses, such as a meeting } \\
\text { business and MICE }\end{array}$ & 339 & 3.23 & 0.63 & middle \\
\hline \multicolumn{5}{|l|}{ Tour Program Arrangement } \\
\hline There is a popular tourist attraction selected & 339 & 4.35 & 0.55 & mostly \\
\hline There is food always fresh, tasty and seasonal & 339 & 4.36 & 0.78 & mostly \\
\hline There is a popular local food included in a tour program & 339 & 4.22 & 0.65 & mostly \\
\hline There is a new, clean and comfortable vehicle selected & 339 & 3.95 & 0.57 & most \\
\hline There are snacks and drinks served between meals & 339 & 3.65 & 0.58 & most \\
\hline $\begin{array}{l}\text { There is a tour program state a date, a time, a tourist attraction and a route } \\
\text { clearly }\end{array}$ & 339 & 3.99 & 0.66 & most \\
\hline There is a tourist safe in terms of his/her body and property & 339 & 4.10 & 0.73 & most \\
\hline There are souvenirs and local food available & 339 & 4.08 & 0.64 & most \\
\hline There is a shop prepared for a tourist & 339 & 4.68 & 0.69 & mostly \\
\hline There is any insurance coverage for a tourist & 339 & 4.78 & 0.77 & mostly \\
\hline There is a stopover for a tourist & 339 & 4.21 & 0.49 & mostly \\
\hline \multicolumn{5}{|l|}{ Competitive Strategy } \\
\hline \multicolumn{5}{|l|}{ Cost Reduction } \\
\hline There are tour routes prepared in order of their distances & 339 & 4.56 & 0.67 & mostly \\
\hline There are an airline or a vehicle selected based on good price and quality & 339 & 4.49 & 0.61 & mostly \\
\hline There is a hotel selected based on good price and quality & 339 & 3.96 & 0.73 & most \\
\hline There is a restaurant selected based on good price and quality & 339 & 3.57 & 0.48 & most \\
\hline There is food reduced for each meal, from 5 kinds of food to 3 kinds of food & 339 & 4.87 & 0.55 & mostly \\
\hline There are any meals canceled, allowing clients to buy them by themselves & 339 & 4.44 & 0.59 & mostly \\
\hline There is a cheaper souvenir shop prepared & 339 & 4.01 & 0.68 & most \\
\hline $\begin{array}{l}\text { There is a tour program joined by tourists, allowing a sufficient number of } \\
\text { tourists for each trip }\end{array}$ & 339 & 3.97 & 0.71 & most \\
\hline \multicolumn{5}{|l|}{ Differentiation } \\
\hline There is a variety of tour programs organized in terms of different prices & 339 & 3.56 & 0.66 & most \\
\hline Can a tour program respond to a tourist's need in terms of prices and places & 339 & 3.98 & 0.59 & most \\
\hline $\begin{array}{l}\text { There is a mixed tour program by having a trip and a free day for optional } \\
\text { tours }\end{array}$ & 339 & 4.59 & 0.70 & mostly \\
\hline There is a tour program with more and less days & 339 & 4.34 & 0.68 & mostly \\
\hline There is a tour program that is excellent and fair for a variety of tourists & 339 & 4.22 & 0.62 & mostly \\
\hline
\end{tabular}

(Table 1 continued on next page) 
(Table 1 continued)

\begin{tabular}{|c|c|c|c|c|}
\hline Variable & $\mathbf{n}$ & mean & S.D. & Result \\
\hline \multicolumn{5}{|l|}{ Business Success } \\
\hline \multicolumn{5}{|l|}{ Marketing Growth } \\
\hline There is a profit increase every year during the past three years & 339 & 4.18 & 0.48 & most \\
\hline There is an income increase every year during the past three years & 339 & 4.65 & 0.56 & mostly \\
\hline There is a market share increase every year during the past three years & 339 & 3.99 & 0.51 & most \\
\hline \multicolumn{5}{|l|}{ Tourist Satisfaction } \\
\hline There is a tourist use a service again & 339 & 3.79 & 0.55 & most \\
\hline There is a tourist advise other tourists to use a service & 339 & 4.11 & 0.59 & most \\
\hline There is any complaint & 339 & 4.04 & 0.63 & most \\
\hline \multicolumn{5}{|l|}{ Efficiency } \\
\hline There is a working activity reduced & 339 & 3.87 & 0.71 & most \\
\hline There is the number of employees reduced, but a working quality is the same & 339 & 3.91 & 0.59 & most \\
\hline There is the working process reduced & 339 & 4.07 & 0.58 & most \\
\hline There is a work quicker & 339 & 4.21 & 0.64 & mostly \\
\hline There is the cost of the consumption of office materials reduced & 339 & 3.99 & 0.61 & most \\
\hline
\end{tabular}

Figure 2. The path Analysis Model

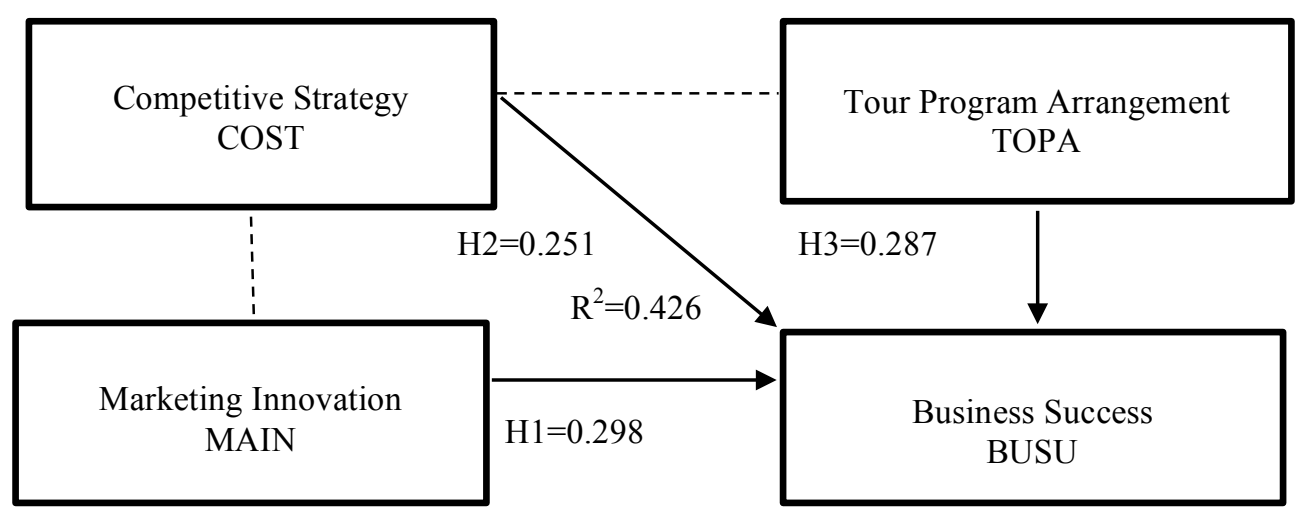

Table 2. Findings on the basis of an overall analysis of the factors influencing Business Success

\begin{tabular}{l|c|c|c|c|c|c|c|}
\hline & \multicolumn{2}{c}{ Assumption } & $\boldsymbol{\beta}$ & t -value & p -value & Result \\
\hline Independent & Dependent & & 0.298 & 3.693 & 0.003 & support \\
\hline H1 & MAIN & BUSU & positively & 0.82 & 0.002 & support \\
\hline H3 & COST & BUSU & positively & 0.251 & 2.828 & 0.001 & support \\
\hline
\end{tabular}

\section{CONCLUSION}

It can be concluded that the policy that tourism business should pay greatest heed to are in the following descending order: marketing innovation, tour program arrangement, and competitive strategy. The statistical values that were explanatory of decision of business success variances were found to hold at 42.6 percent $(\mathrm{R} 2=0.426)$.

In addition, it would be well if business success considered the most appropriate management as follows: (1) to marketing growth (2) to customer satisfaction; (3) to efficiency. Finally, important factors to be used in the tourism business were altogether forty-five in number.

\section{AUTHOR BIOGRAPHY}

Dr. Chayanan Kerdpitak is a Lecturer and Head of Master of Business Administration (MBA) and Management committee of Doctor of Business Administration (DBA) at Valaya Alongkorn Rajabhat University in Thailand. She 
received a Ph.D. in the field of Business at Ramkhamhaeng University, Bangkok, Thailand. In addition, she graduated a B.B.A and M.B.A in Business Administration from The Ramkhamhaeng University, Bangkok, Thailand (Major in Marketing).

\section{REFERENCES}

Balmer, J.M.T. \& Greyser, S.A. (2006). Corporate marketing: Integrating corporate identity, corporate branding, corporate communications, corporate image and corporate reputation. European Journal of Marketing, 40(7), 730-741.

Barney, J.B. (1991). Firm resources and sustained competitive advantage. Journal of Management, 17(1), 99-120.

Barney, J.B. (2001). Resource-based theories of competitive advantage: A ten-year retrospective on the resource-base view. Journal of Management, 27, 643-649.

Barrister, E.O. Lyiola, O.O, \& Osibanjo, A. O. (2014). Managing workplace conflicts in business environment: The role of alternative dispute resolution (ADR). European Journal of Business and Management, (6)36.

Certo, S.C \& Certo, S.T. (2012). Modern Management, Concept and Skill. 12th Edition. Pearson Edition.

Chen, K.J. (1998). The effect of satisfaction and familiarity on intention: multiple-destination context. Journal of International Consumer Marketing, 10(1/2), 159-173.

Connell, J. (2012). Film tourism - evolution, progress and prospects. Tourism Research, 33, 1007 - 1029.

Crotts, J. \& Bing, P. (2007). Destination Appraisals, Annals of Tourism Research, 34(2), 541-544.

Department of Tourism: Ministry of Tourism and Sports. (2016). Visitors statistic in Thailand, Retrieved from http://www.tourism.go.th/home/details/11/221/24246.

Dimanche, F. \& Havitz, M.E. (1994). Consumer behavior and tourism: review and extension of four study areas. Journal of Travel and Tourism Marketing, 3(3), 37-57.

He, H. \& Li, Y. (2011). CSR and service brand: The mediating effect of brand identification and moderating effect of service quality. Journal of Business Ethics, 100, 673-688.

Hwang, S.N., Lee, C. \& Chen, H.J. (2005). The relationship among tourists' involvement, place attach and interpretation satisfaction in taiwan's national parks. Tourism Management, 26, 143-156.

Kerdpitak C. \& Heuer K. (2013). Influencing of marketing competency in aviation industry. International Journal of Business Tourism and Applied Sciences, 1(1), 1-11.

Kerdpitak, C. \& Heuer, K. (2016). Key Success Factors of Tourist Satisfaction in Tourism Services Provider, 32(4), 1237-1242.

Kotler, P. (1997). Marketing Management. Upper saddle, New Jersey: Prentice Hall.

Kozak, M. (2002). Comparative analysis of tourist motivations by nationality and destination. Tourism Management, 23, 221232.

Kozak, M. \&Rimmington, M. (2000). Tourist satisfaction with mallorca, spain as an off-season holiday destination. Journal of Travel Research,38 (February), 260-269.

Martínez, P. \& del Bosque, I., R. (2013). CSR and customer loyalty: The roles of trust, customer identification with the company and satisfaction. International Journal of Hospitality Management, 35, 89-99.

Martínez, P., Pérez, A. \& del Bosque, I., R. (2014). Exploring the role of CSR in the organizational identity of hospitality companies: A case from the Spanish tourism industry. Journal of Business Ethics, 124, 47-66.

Oliver R. \& Swan, J.E. (1989). Consumer perceptions of interpersonal equity and satisfaction in: transaction: a field survey approach. Journal of Marketing, 53(April), 21-35.

Park, D. B., Lee, K. W., Choi, H. S., \& Yoon, Y. (2012). Factors influencing social capital in rural tourism communities in South Korea. Tourism Management, 33(6), 1511-1520.

PATA. (2012) Asia Pacific Visitor Forecasts 2014-2018 Report. http://www.mekongtourism.org/key-findings-preliminary-asiapacific-visitor-forecasts-2014-2018-report/.

Pennington-Gray, L., Schroeder, A., \& Gale, T. (2014). Co-management as a framework for the development of a tourism area response network in the rural community of Curanipe, Maule Region, Chile. Tourism Planning \& Development, 11(3), 292-304.

Pimpunchat, B., Sirimangkhala, K., \& Junyapoon, S. (2014). Modeling Haze Problems in the North of Thailand using Logistic Regression. Journal of Mathematical and Fundamental Sciences, 46(2), 183-193.

Porter, M.E. (1985) Competitive advantage: Creating and sustaining superior performance. New York: The Free Press.

Porter, M.E. (1990) The competitive advantage of nations. New York: The Free Press.

Vargas, G., Cardenas, L. \& Matarranz, L. (2000). Internal and External Integration of Assembly Manufacturing Activities, International Journal of Operation and Production Management, 20(7), 809-822.

World Travel and Tourism Council. (2015). Travel and tourism economic impact Asia Pacific 2015. http://www.hospitalitynet.org/news/4069673.html

Yamane, T. (1973). Statistics: An Introductory (3rd ed). New York Harper and Row Publication. 


\section{NOTES}

